\title{
Method for Psychological Status Monitoring with Line of Sight Vector Changes (Human Eye Movements) Detected with Wearing Glass
}

\author{
Kohei Arai ${ }^{1}$ \\ Graduate School of Science and Engineering \\ Saga University \\ Saga City, Japan
}

\author{
Kiyoshi Hasegawa ${ }^{2}$ \\ ${ }^{2}$ Hitachi Co. Ltd. \\ Tokyo, Japan
}

\begin{abstract}
Method for psychological status monitoring with line of sight vector changes (human eye movement) detected with wearing glass is proposed. Succored eye movement should be an indicator of humans' psychological status. Probability of succored eye movement, therefore, is measured. Through experiments with simple and complicated documents, relation between psychological status measured with eeg signals and the probability of succored eye movements is clarified. It is found that there is strong relation between both results in psychological status can be estimated with eye movement measurements.
\end{abstract}

Keywords—psychological status; eye movement; eye detection and tracking; eeg signal;

\section{INTRODUCTION}

The number of blink increases in accordance with angrily nevus, excitations while it decreases in accordance with concentration, cares. In accordance with Asher \& Ort (1951), fixed eye status is affected by emotional words stimulating human brain with eye jerk movement in horizontal direction, frequent blink, and eye close [1]. Antrobus et al. (1964) said that eye movement when human actively think about something is much active than that when human think about something passively [2]. Stoy (1930) also said that eye movement when human look at spatial materials is much active than that when human look at non spatial materials [3]. Meanwhile, Greenberg (1970) said that optokinetic nystagmus increases when human calculation by heart for complicated calculations in comparison to that when human calculate by heart for simple calculations [4]. These studies are conducted with users who do not move at all. As mentioned above, there is strong relation between psychological status and eye movement. In particular, succored movement has a strong relation to psychological status.

Eye movements can be detected and tracked with camera images even if users are moving. By using glass mounting near infrared camera with near infrared light sources, acquired images do not affect by illumination condition changes and also it allows users' movements [5]-[10]. Therefore, eye movement detection and tracking can be done through users' movement results in estimation of psychological status monitoring during users' movement.

The proposed method and system allows such this functionality of psychological status monitoring under users' movement conditions. Through experiments with simple and complicated documents, relation between psychological status measured with eeg signals and the probability of succored eye movements is clarified. It is found that there is strong relation between both results in psychological status can be estimated with eye movement measurements.

The following section describes the proposed method and system followed by experiments. Then final section describes conclusion with some discussions.

\section{PROPOSED METHOD AND SYSTEM}

\section{A. System Architecture}

The proposed system consists of the glass which mounts near infrared camera with near infrared LED: Light Emission Diodes which are aligned surrounding to the optical entrance of near infrared camera. Figure 1 shows outlook of the glass while major specification is shown in Table 1.

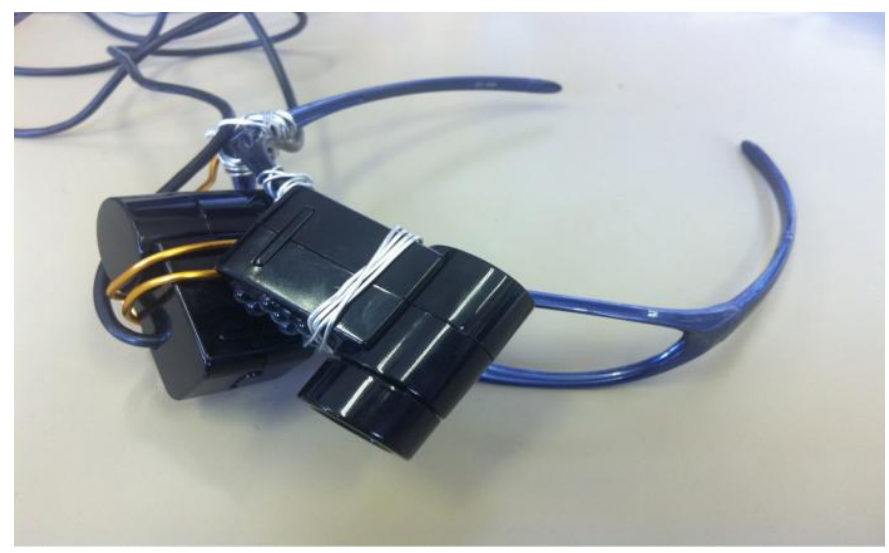

Fig. 1. Outlook of the glass mounting near infrared camera with near infrared LEDs

The glass is mounting two cameras, one is for acquiring human eye and the other camera is for acquiring the image at which user looks. As shown in Table1, camera has LED of light source so that eye movement can be detected and tracked without influence due to illumination condition changes Also, the glass moves in accordance with head movements so that the proposed system allows users' movement. 
TABLE I. SPECIFICATION OF NEAR INFRARED: NIR CAMERA

\begin{tabular}{|c|c|}
\hline Pixel & $1.3 \mathrm{M}$ \\
Resolution & $1280 \times 1024$ \\
Frame rate & $1280 \times 1024: 7.5 \mathrm{fps}, 640 \times 480: 30 \mathrm{fps}$ \\
Dimension & $52 \mathrm{~mm}(\mathrm{~W}) \times 65 \mathrm{~mm}(\mathrm{D}) \times 70 \mathrm{~mm}(\mathrm{H})$ \\
Weight & $85 \mathrm{~g}$ \\
Operating condition & $0-40 \mathrm{deg} . \mathrm{C}$ \\
Interface & SB 2.0 \\
IR Illumination & 7 IR LED \\
& \\
\hline
\end{tabular}

\section{EXPERIMENTS}

\section{B. Experimental Method}

The experiments are conducted with eeg sensor. Eeg sensor of brain catcher manufactured by Noryoku Kaihatsu Co. Ltd. is used. Outlook of the eeg sensor is shown in Figure 2. Major specification of eeg sensor is shown in Table 2.

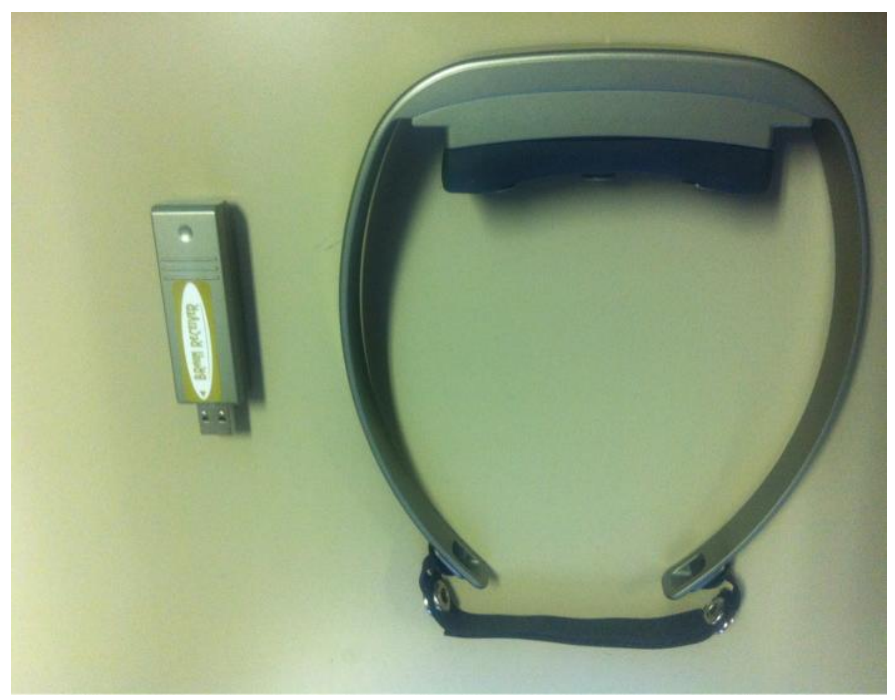

Fig. 2. Outlook of the eeg signal acquisition sensor of brain catcher manufactured by Noroku Kaihatsu Co. Ltd. is used.

TABLE II. SPECIFICATION OF EEg SENSOR

\begin{tabular}{|l|l|}
\hline Frequency coverage & $4 \mathrm{HZ} \sim 24 \mathrm{HZ} \quad \pm 3 \mathrm{~dB}$ for eeg \\
\hline Frequency coverage & $150 \mathrm{HZ} \sim 800 \mathrm{HZ} \quad \pm 3 \mathrm{~dB}$ for emg \\
\hline Sampling frequency & $1024 \mathrm{~Hz}$ \\
\hline Quatization bit & $10 \mathrm{bit}$ \\
\hline Input impedance & $10 \mathrm{M} \Omega$ \\
\hline
\end{tabular}

\section{Preliminary Experimental Results on Gaze Estimation Accuracy}

System starts with find the location of pupil. After pupil location is found, next is converts into gaze angle. As we see in Figure 3, the single camera is used and the position is mounted on user's glass.

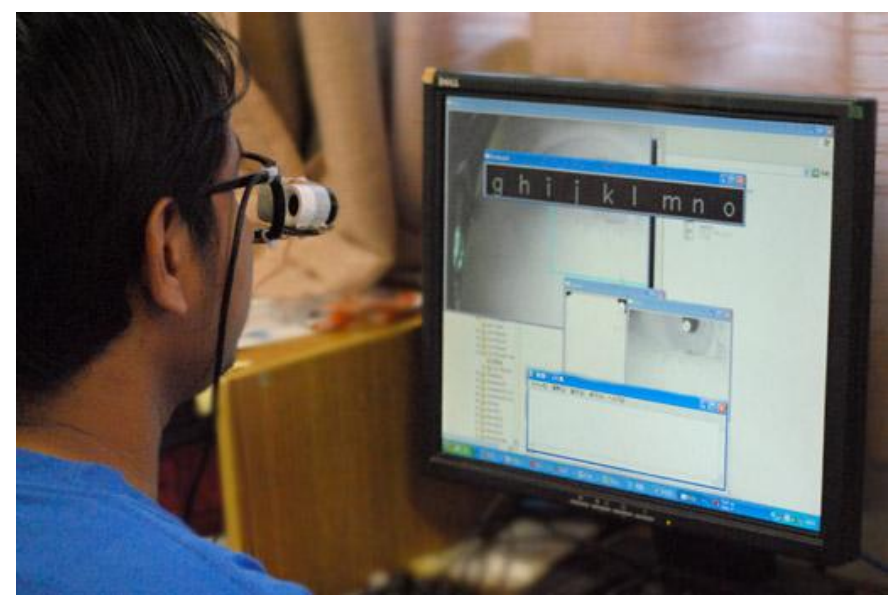

Fig. 3. Eye detection and tracking

It means that between camera and display is separated each others. Because of this, should has the connector that will connect between camera mounted on user's glass and display monitor in order to obtain that what user's look is same position with pointer in display. In order to connect them, the calibration is required. After user wearing the glass, user looks at four corners on display. By using the adjustment method, the user's gaze output will correlate with the pointer.

Gaze estimation accuracy is measured at the middle center to horizontally aligned five different locations with the different angles as shown in Figure 4. The experimental result shows the gaze estimation error at the center middle (No.1) shows zero while those for the angle ranges from -5 to 15 degrees is within 0.2 degree of angle estimation error as shown in Table 3.. Because the user looks at the center middle with 5 degree allowance results in 0.2 degree of gaze estimation accuracy.

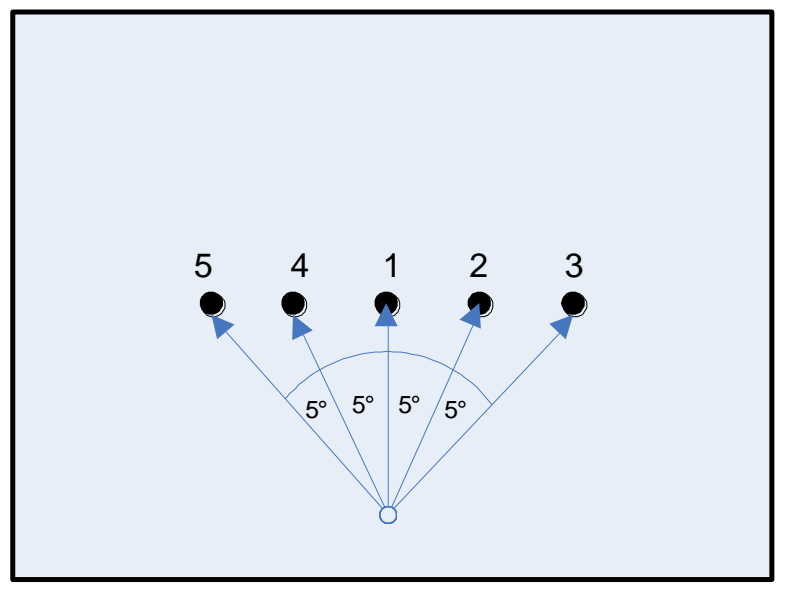

Fig. 4. Measuring accuracy 
TABLE III. GAZE ESTIMATION ACCURACY AT THE DESIGNATED VIEWING ANGLES

\begin{tabular}{|c|c|c|c|c|c|}
\hline Point & $\mathbf{1}$ & $\mathbf{2}$ & $\mathbf{3}$ & $\mathbf{4}$ & $\mathbf{5}$ \\
\hline Error(degree) & 0 & 0.2 & 0.2 & 0.2 & 3.12 \\
\hline
\end{tabular}

\section{Documents Used for the Experiments}

Two documents, relatively simple and comparatively complicated documents are prepared. Two documents are shown in Figure 5 (a) and (b). Four students read the two documents in almost same conditions. During students read two documents, eeg signals are acquired. The frequency components are analyzed with FFT: Fast Fourier Transformation. Then maximum frequency component is used for characterization of psychological status.

\section{E. Preliminary Experimental Results of Maximum Frequency of eeg Signals}

Eeg signals are acquired when a student is taking a rest and learn hard with e-learning contents. Maximum frequency of eeg signals are calculated at the same time. Figure 6 (a) shows an example of maximum frequency at when the student is taking a rest while Figure 6 (b) shows that at when the student is learning with e-learning contents, respectively. As shown in Figure 6, maximum frequency at when the student is learning is much higher than that at when the student is taking rest, obviously.

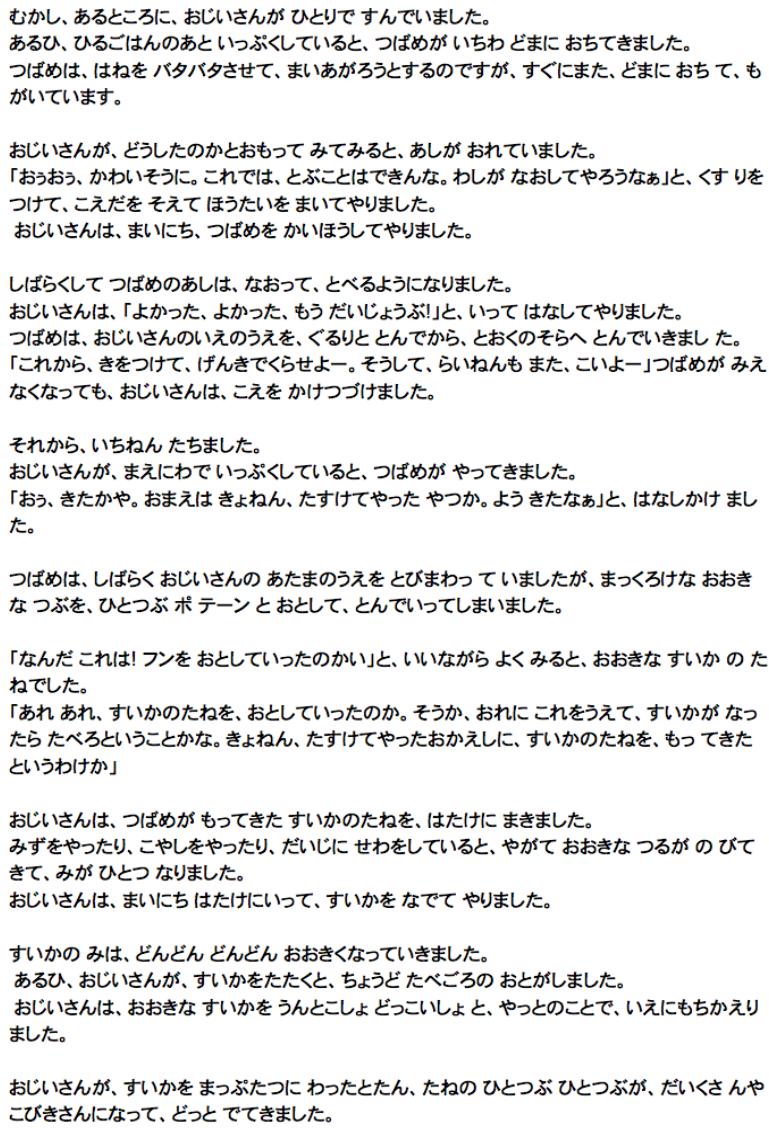

(a)Relatively simple document
脳波（のうは、Electroencephalogram：EEG）は、ヒト・動物の脳から生じる電気 活動を、頭皮上、蝶形骨底、鼓膜、脳表、脳深部などに置いた電極で記録したもの である。

英語のElectroencephalogramの忠実な訳語として、脳電図、EEGという呼び方もあ り、中国語ではこちらの表現法を取っている。

本来は、脳波図と呼ぶべきであるが、一般的には「脳波」と簡略化して呼ばれるこ とが多い。

脳波を測定、記録する装置を脳波計(Electroencephalograph：EEG)と呼び、それを 用いた脳波検査(Electroencephalography：EEG)は、医療での臨床検査として、また 医学、生理学、心理学、工学領域での研究方法として用いられる。

検査方法、検查機械、検査結果のどれも略語はEEGとなるので、使い分けに注意が 必要である。

個々の神経細胞の発火を観察する単一細胞電極とは異なり、電極近傍あるいは遠隔 部の神経細胞集団の電気活動の総和を観察する（少数の例外を除く）。 近縁のものに、神経細胞の電気活動に伴って生じる磁場を観察する脳磁図（のうじ ず、Magnetoencephalogram : MEG）がある。 直接記録する方法はしばしば臨床検査として用いられる。背景脳波（基礎律動）や 突発活動（てんかん波形など）を観察する。

各種のてんかん、ナルコレプシー、変性疾患、代謝性疾患、神経系の感染症、脳器 質的疾患、意識障害、睡眠障害、精神疾患などの診断の補助・状態把握などに用い られる。

波形の加工の方法として、主なものに加算平均法、双極子推定法、周波数解析、コ ヒーレンス法、主成分分析、独立成分分析などがあり、一部は臨床でも用いられてい る。

脳波を直接記録する方法はしばしば臨床検査として用いられる。背景脸波（基礎律 動）や突発活動（てんかん波形など）を観察する。

各種のてんかん、ナルコレプシー、変性疾患、代謝性疾患、神経系の感染症、脳器 質的疾患、意識障害、睡眠障害、精神疾患などの診断の補助・状態把握などに用い られる。

波形の加工の方法として、主なものに加算平均法、双極子推定法、周波数解析、コ ヒーレンス法、主成分分析、独立成分分析などがあり、一部は臨床でも用いられてい る。

(b)Comparatively complicated document

Fig. 5. Two documents used for the experiments

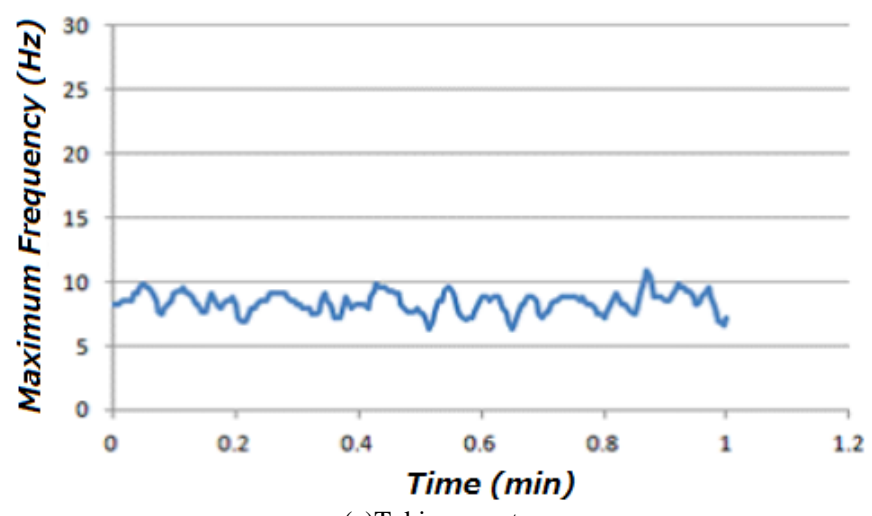

(a)Taking a rest 


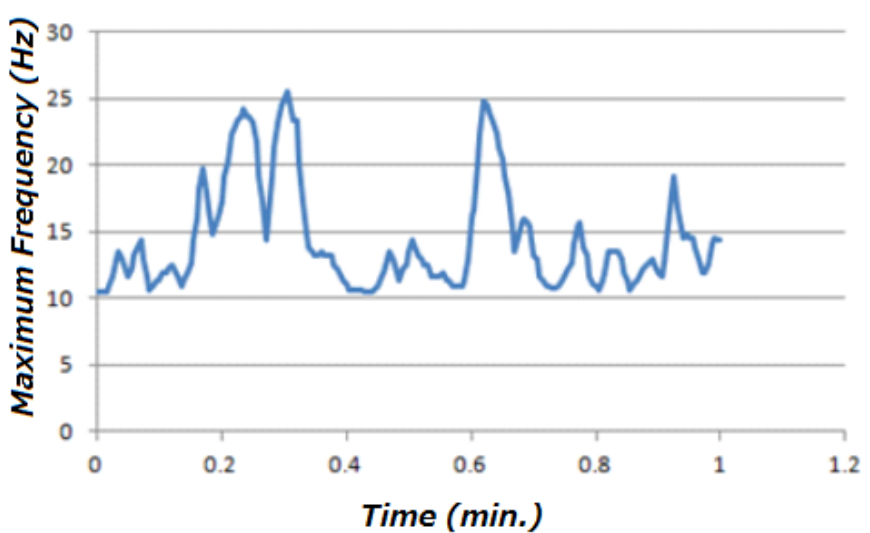

(b)Learning with e-learning contents.

Fig. 6. eeg derived maximum frequency comparison

\section{F. Experimental Results}

Figure 7 shows eeg signals of the students A to D when they are reading the relatively simple document. Meanwhile, Figure 8 shows those for the students A to D when they read the comparatively complicated document. Each student shows a little bit different trend of the maximum frequency. Namely, each student feels difficultness or easiness of the document differently. The maximum frequency for the relatively simple document is below $10 \mathrm{~Hz}$ while that for the comparatively complicated document shows more than $10 \mathrm{~Hz}$ in particular more than $15 \mathrm{~Hz}$ for three students. Alpha frequency ranged from 8 to $13 \mathrm{~Hz}$. Averaged maximum frequencies over the time for reading the relatively simple documents for the student $\mathrm{A}$ to D are 6, 7, 9, and 10, respectively. On the other hand, averaged maximum frequencies over the time for reading the relatively complicated documents for the student $\mathrm{A}$ to $\mathrm{D}$ are $23,20,15$, and 14 . Therefore, difference of maximum frequencies between relatively simple and comparatively complicated documents is significant.

Therefore, most students read the relatively simple document in a relax situation while most students read the comparatively complicated document in a irritated situation because their maximum frequency component shows beta frequency dominantly.

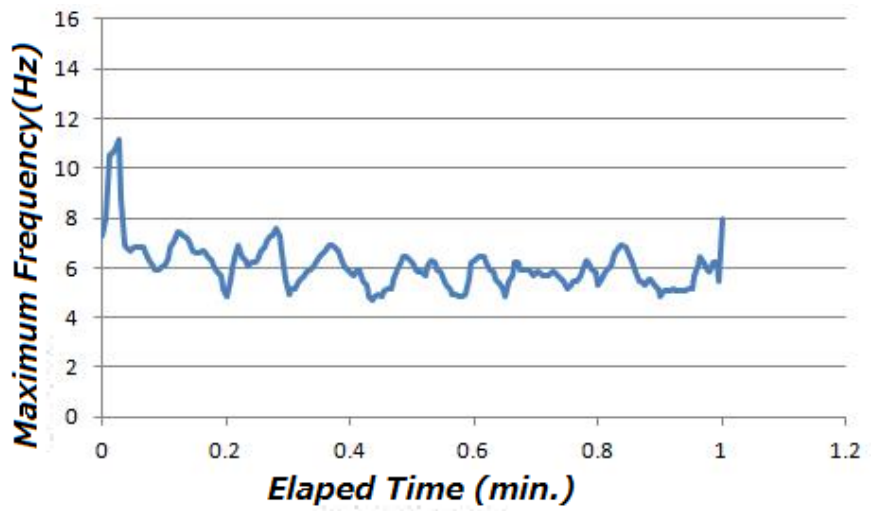

(a)Student A

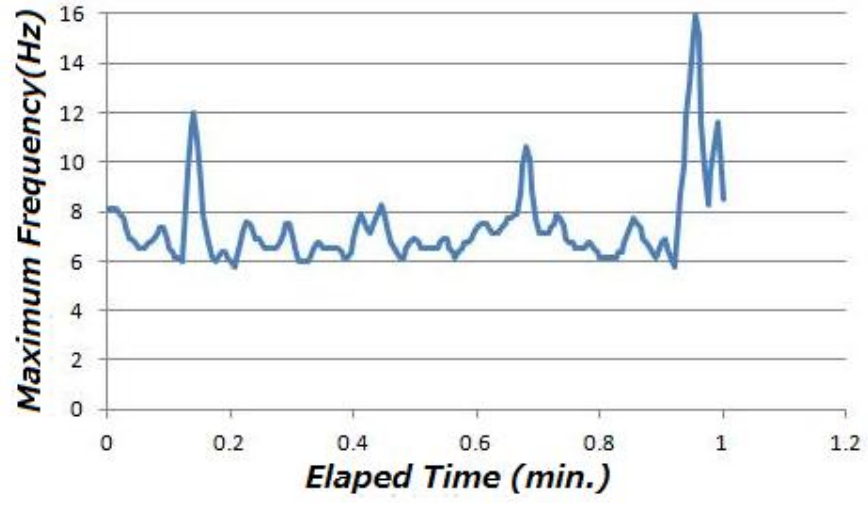

(b)Student B

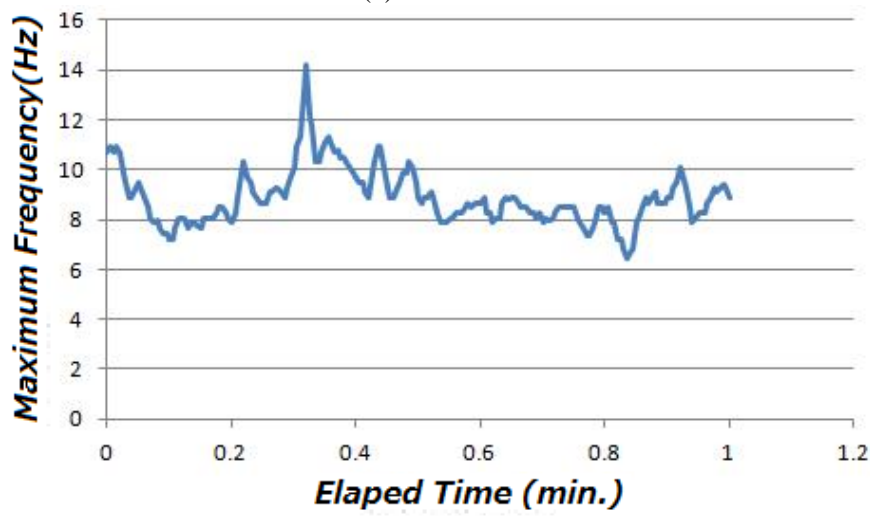

(c)Student C

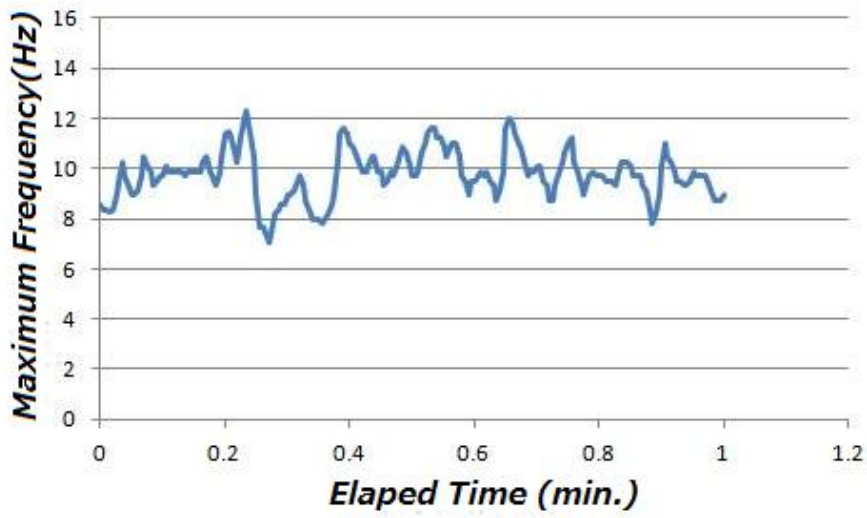

(d)Student D

Fig. 7. Maximum frequency during the students read the relatively simple document

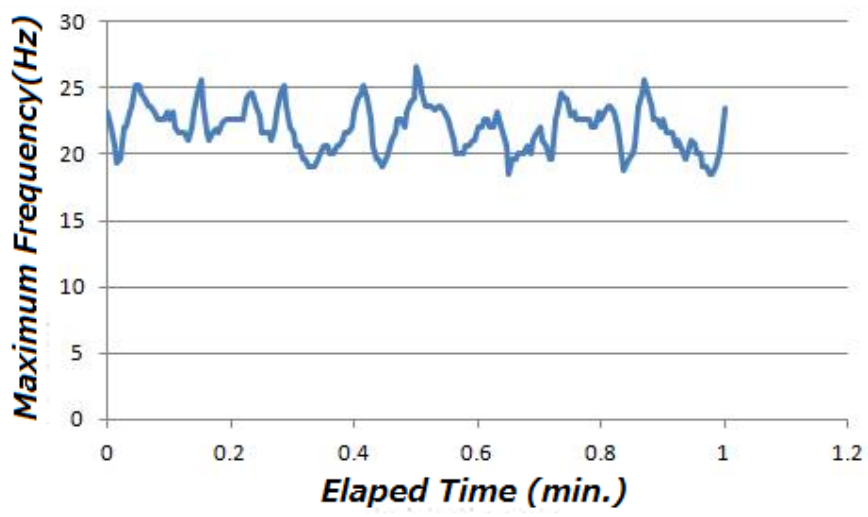

(a)Student A 


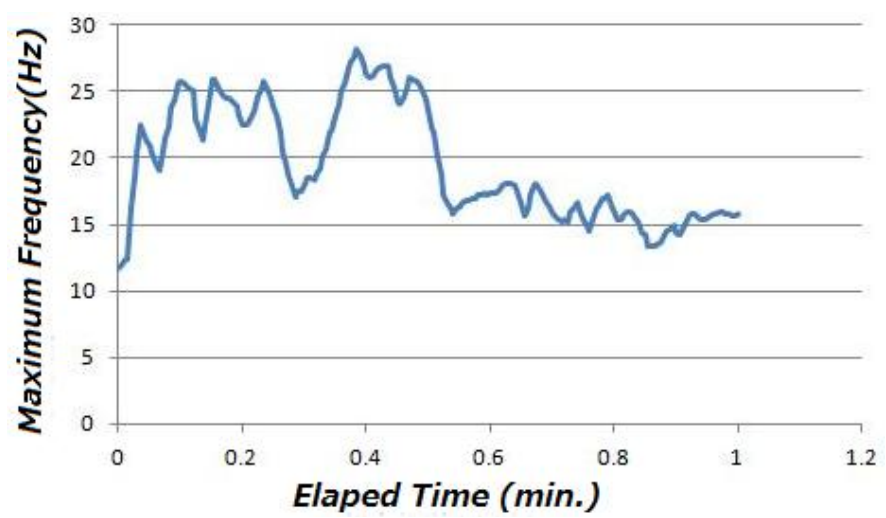

(b)Student B

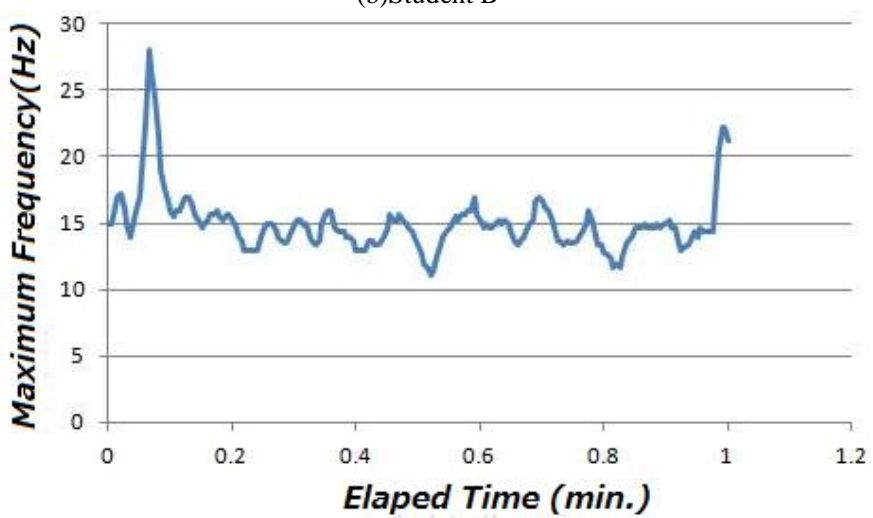

(c)Student C

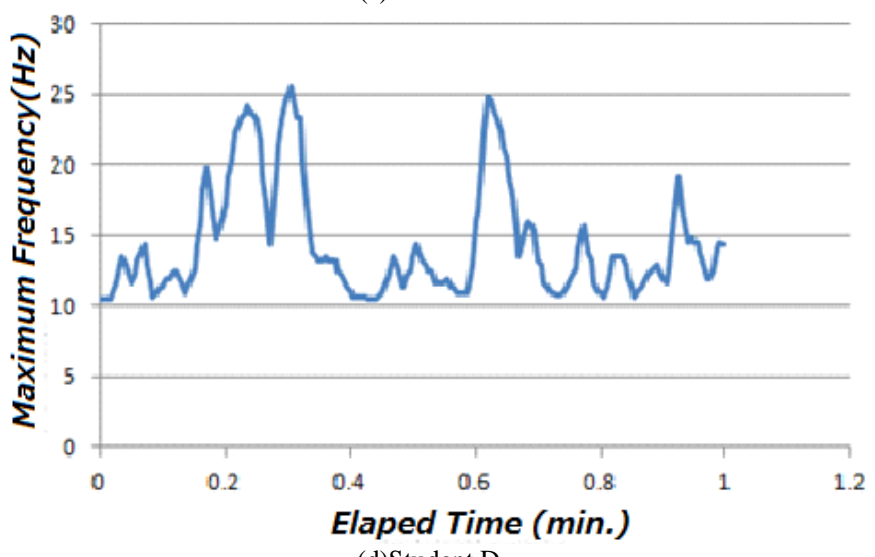

(d)Student D

Fig. 8. Maximum frequency during the students read the relatively complicated document

Figure 9 shows the maximum frequency of eeg signal when the students read the two documents. Figure 10 shows the number of succored eye movement a second when the students are reading the two documents. Succored movements are detected with the acquired students' eye images through image analysis based on template matching. The number of succored movements for the relatively simple document is less than that for the comparatively complicated document, obviously. Furthermore, the difference of the number of succored movement between the two documents is dependent on each student.

Furthermore, Figure 11 shows the remarkable moments of the maximum frequency when the students are reading the comparatively complicated document. In the figure, the first red circle is situated when the students read the word "Electroencephalogram" while the second red circle is situated when the students read the word of “ナルコレプシー” and the third red circle indicates at when the students read the word of “双極子推定法”, respectively. These words are totally new for the students so that they had to read again the words.

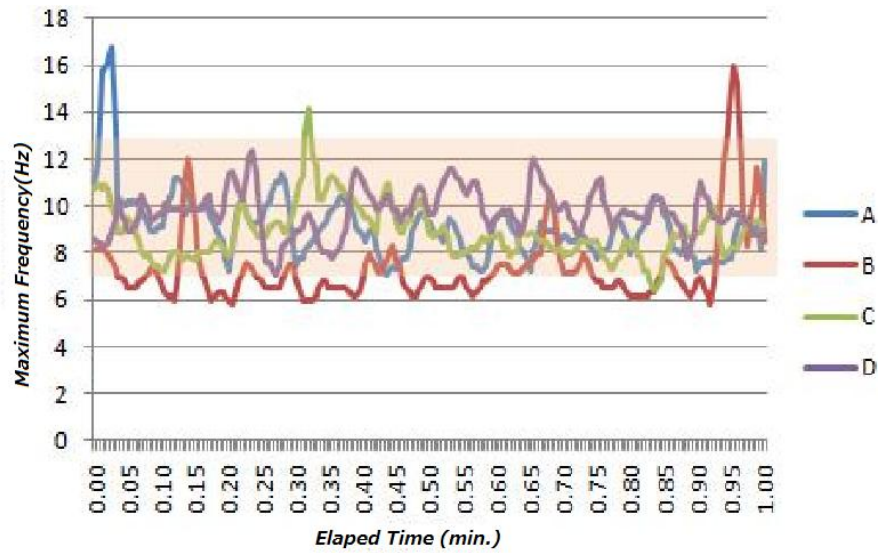

(a)Relatively simple document

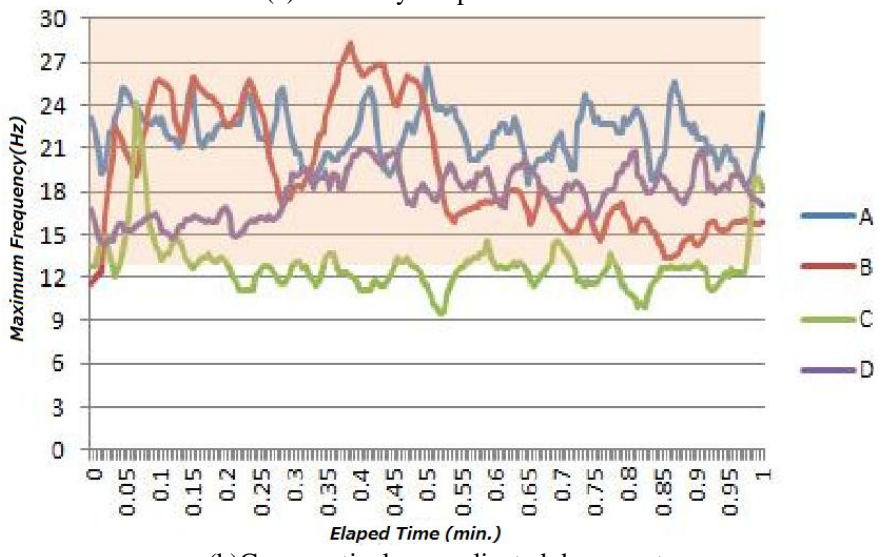

(b)Comparatively complicated document

Fig. 9. Maximum frequency of eeg signal when the students read the two documents

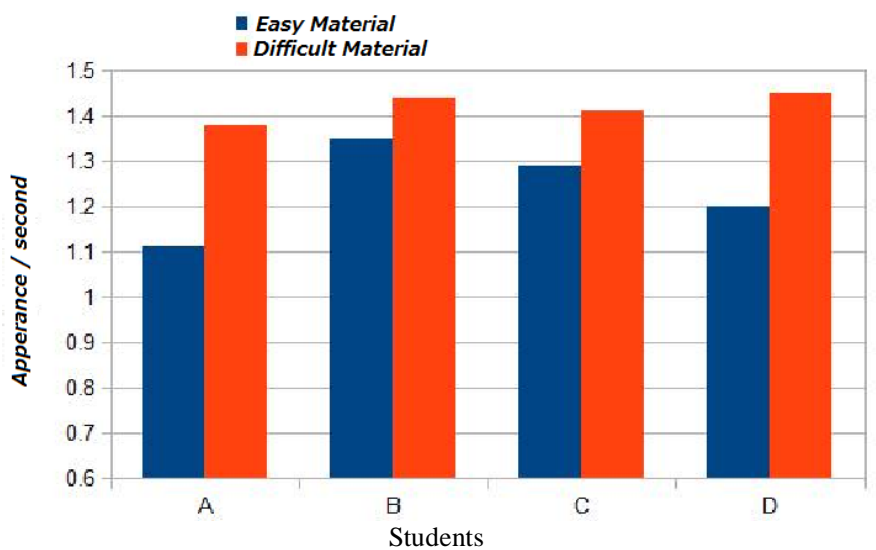

Fig. 10. The number of succored eye movement a second when the students are reading the two documents 


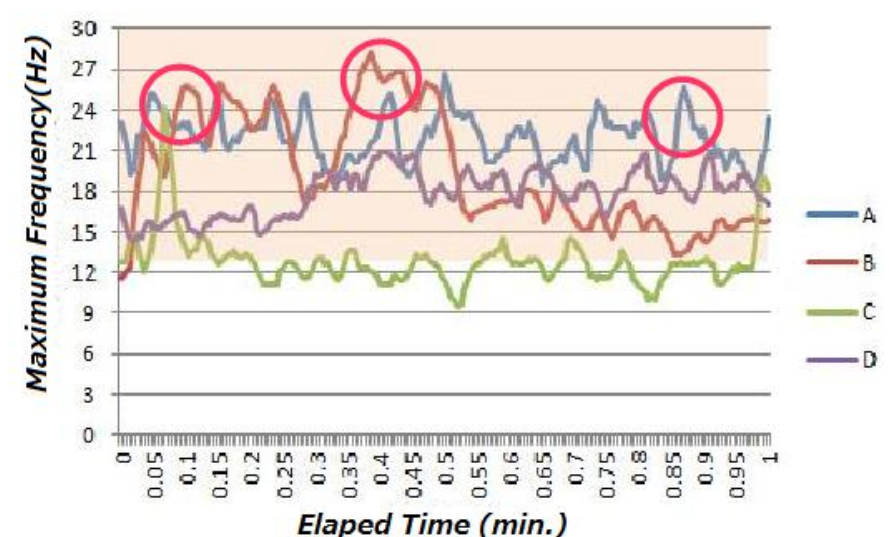

Fig. 11. The remarkable moments of the maximum frequency when the students are reading the comparatively complicated document.

The first red circle is situated when the students read the word "Electroencephalogram" while the second red circle is situated when the students read the word of “ナルコレプシー” and the third red circle indicates at when the students read the word of “双極子推定法”, respectively..

\section{CONCLUSION}

Method for psychological status monitoring with line of sight vector changes (human eye movement) detected with wearing glass is proposed. Succored eye movement should be an indicator of humans' psychological status. Probability of succored eye movement, therefore, is measured. Through experiments with simple and complicated documents, relation between psychological status measured with eeg signals and the probability of succored eye movements is clarified. It is found that there is strong relation between both results in psychological status can be estimated with eye movement measurements.

\section{ACKNOWLEDGMENT}

The authors would like to thank Ms. Mayu Osumi for her effort to conduct the experiments together with the students who participated to the experiments.

\section{REFERENCES}

[1] S. Brin and L. Page. The anatomy of a large-scale hypertextual Web search engine. Computer Networks and ISDN Systems, 30(1 \{7):107\{117, 1998.

[2] Ruggieri, V., The running horse stops: the hypothetical role of the eyes in imagery ofmovement, Perceptual and Motor Skills, 89, 1088-1092 (1999).

[3] Mariko Takeda, Effect of mental activity in problem solving on eye movement, The Japanese Journal of Ergonomics, 12, 175-181 (1976)

[4] Asher, E. J . \& Ort, R. S ., Eye movement as a complex indicator, J. Gen. Psychol.,45, 209-217 (1951).

[5] Antrobus, J. S., Antrobus, J. S., \& Singer, J. L., Eye movements accompanying daydreaming, visual imagery, thought suppression, $J$. Abnorm. Soc. Psychol., 69, 244-252 (1964).

\section{AUTHORS PROFILE}

Kohei Aarai He received BS, MS and PhD degrees in 1972, 1974 and 1982, respectively. He was with The Institute for Industrial Science and Technology of the University of Tokyo from April 1974 to December 1978 and also was with National Space Development Agency of Japan from January, 1979 to March, 1990. During from 1985 to 1987, he was with Canada Centre for Remote Sensing as a Post Doctoral Fellow of National Science and Engineering Research Council of Canada. He moved to Saga University as a Professor in Department of Information Science on April 1990. He was a councilor for the Aeronautics and Space related to the Technology Committee of the Ministry of Science and Technology during from 1998 to 2000. He was a councilor of Saga University for 2002 and 2003. He also was an executive councilor for the Remote Sensing Society of Japan for 2003 to 2005. He is an Adjunct Professor of University of Arizona, USA since 1998. He also is Vice Chairman of the Commission-A of ICSU/COSPAR since 2008 He wrote 30 books and published 332 journal papers. 